\title{
ALTERNATYVIOS ENERGETIKOS STATINIŲ IR İRENGINIŲ POVEIKIO PASTATŲ ARCHITEKTŪRAI IR PAJŪRIO KRAŠTOVAIZDŽIAMS ASPEKTAI
}

\author{
Petras Grecevičius ${ }^{1}$, Jonas Abromas ${ }^{2}$, Vytautas Dubra ${ }^{3}$ \\ Kraštovaizdžio architektūros ir aplinkos planavimo katedra, \\ Jūrinio kraštovaizdžio mokslo institutas, Klaipedos universitetas, \\ H. Manto g. 84, LT-92295 Klaipéda, Lietuva

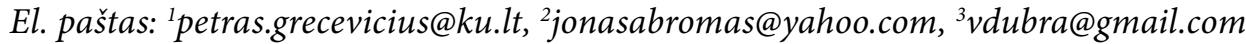

Iteikta 20091013

\begin{abstract}
Santrauka. Pasaulinės bendruomenès deklaruojamos darnaus vystymosi nuostatos įpareigoja analizuoti atskirų šalies regionų ir gyvenviečių galimybes, išteklius tam, kad kuo greičiau itin pagerintume kiekvieno žmogaus gyvenimo kokybę. Pastaruoju laikotarpiu Vakarų Lietuvos teritorijos kraštovaizdyje vis labiau daugèja urbanizacijos ženklų, darančių negatyvų poveikị regiono identitetui, istorinès ir gamtinės aplinkos vertybėms. Tankëja užstatymas gyvenamaisiais pastatais tarp atskirų pajūrio gyvenviečių. Pastaruoju laikotarpiu regione įrengta keliolika vejjo jeggainių kompleksų, kai kur pastatytos pavienès jègainès. Deja, jègainès statomos labai arti gyvenamụjų teritorijų, kultūros paveldo ir kraštovaizdžio vertybių. Jau planuojama įrengti vèjo jègainių laukus atviroje jūroje. Matyt, greit jūroje atsiras ir bangų energiją panaudojančios konstrukcijos. Ant pastatų stogų irengiami pavieniai saulès kolektoriai. Renovuojamos arba statomos naujos nedidelès hidraulinès jègainès. Regione yra perspektyvūs geoterminio vandens ištekliai. Visa tai neabejotinai jau daro ịtaką architektūrinei pastatų bei pajūrio kraštovaizdžių raiškai. Ateityje ta ịtaka dar labiau didès. Siekiant aukštos Lietuvos pajūrio kraštovaizdžių estetinès vertès, išsaugoti savitumą, būtina daug reglamentuojančių ir planavimo bei teisinių priemonių, kurios garantuotų aukštą kraštovaizdžio kokybę ne tik artimiausiais metais, bet ir tolimoje perspektyvoje. Šiame straipsnyje analizuojami kai kurie Lietuvos pajūrio gyvenviečių darnaus vystymosi aspektai, susieti su naujų energetinių ịrenginių ir statinių poveikiu architektūrinei aplinkai, pateikiami preliminarūs siūlymai ieškant sprendimų, kaip naujus aplinkos elementus kuo tinkamiau išnaudoti gerinant pastatų architektūrą, praturtinant kraštovaizdžius.

Reikšminiai žodžiai: kraštovaizdis, alternatyvi energetika, architektūra, darnus vystymas, identitetas.
\end{abstract}

\section{Ivadas}

Pastaraisiais metais pajūrio kraštovaizdyje vyko kardinalūs struktūriniai pokyčiai, kurie iš esmès pakeitè situaciją Lietuvos pajūrio Būtingės-Klaipėdos ruože. Labai išaugo pajūrio ruožo urbanizacijos lygis. Dèl nemotyvuotos ir chaotiškos urbanistinès pletros, ydingos teritorijų planavimo tvarkos ir kitų priežasčių vis didejja pajūrio kraštovaizdžio kokybės palaikymo ir gerinimo problemos, nyksta svarbūs rekreacinès aplinkos komponentai (Grecevičius 2005). Pajūryje intensyviau statomos naujos vejjo jègainès, kurių integravimas ị jau susiformavusią urbanistinę struktūrą kelia aplinkosauginių, kraštovaizdžio kokybès problemu (Grecevičius 2001).

Problema - sisteminio požiūrio i̇ pajūryje vykstančius procesus stygius. Vyrauja pavieniai tyrimai, orientuoti $\mathfrak{i}$ atskiras problemas, neieškant priklausomybės ryšių tarp atskirų erdvinès struktūros objektų. Alternatyvios energetikos objektai įrengiami neturint būtinų tokiu atveju mokslinių urbanistinių, architektūrinių bei kraštovaizdžio tyrimų, nevykdomi išsamūs jau ịrengtų jẻgainių poveikio aplinkai natūriniai tyrimai. Nevykdomas sisteminis pajūrio kraštovaizdžių būklès monitoringas, kurio duomenimis galima būtų naudotis formuojant teritorinius sprendinius. Vykdomi ilgamečiai tik kai kurių aplinkos komponentų tyrimai (žolinès augalijos, povandeninio kultūros paveldo, rekreacinių srautų, priekrantės ar jūrinès biologinès ivairovès, krantų formavimosi procesų ir kt.).

Lietuvos teritorijos ir Klaipėdos apskrities bendrųjų planų sprendiniuose teigiama, kad ypatingas vals- 
tybės dėmesys pajūryje skirtinas rekreacijos plètotei (Vakarų... 2002, Lietuvos... 2002). O intensyvejjant užstatymui rekreacinis regiono potencialas menksta. Kai kurių Lietuvos pajūrio gyvenviečių, rekreacinių ir kitų teritorijų šiandieninis ịspūdis labai prastas, kraštovaizdis vis labiau praranda savitumo ženklus, mažèja pajūrio ruožo rekreacinis imlumas. Tipinių energetinių irrenginių gausèjimas mažina regiono architektūrinị savitumą. Senieji malūnai tapo regiono kraštovaizdžio vertybèmis, o naujos vejjo jegainès pernelyg disonuoja su gamtiniu kraštovaizdžiu (1 pav.). Todèl būtina kuo skubiau ieškoti priemonių, kaip naudoti naujus tipinius elementus, užtikrinant pastatų ir kraštovaizdžių savitumą.
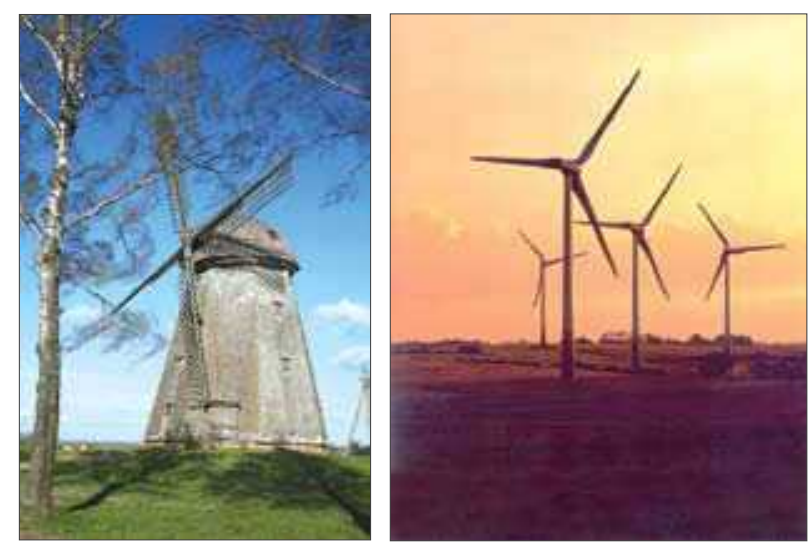

1 pav. Malūnai kraštovaizdyje: senasis malūnas Lazdininkuose ir vejo jègainių ferma Kretingos rajone

Fig. 1. Mills in the landscape: old mill in Lazdininkai and windpowerstation farm in Kretinga district

Tyrimų tikslas - darnus Lietuvos pajūrio urbanistinis vystymas.

Objektas - Lietuvos pajūrio kraštovaizdžiu erdvinè teritorinè struktūra.

Tyrimų metodai - originalūs autorių tyrimai, atlikti rengiant Vakarų Lietuvos darnaus urbanistinio vystymo strategiją 2005-2025 metų laikotarpiui.

Metodika: natūriniai tyrimai, sisteminè analizè, lyginamoji analizè, užslèptų struktūrų tyrimai, procesų dinamikos modeliavimas.

\section{Alternatyvios energetikos statiniai ir ịrenginiai Vakarų Lietuvoje}

Pasaulyje vis labiau telkiamas dèmesys ir pastangos sprendžiant problemas, kaip žmonių energetiniams poreikiams geriau panaudoti atsinaujinančius ir alternatyvius energijos šaltinius. XX a. paskutiniame dešimtmetyje labai paspartėjo alternatyvios energetikos panaudojimo tempas. Daug nuveikta ir intensyviai tebedirbama saulès, vejjo, hidroenergijos, biomasès, biodujų naudojimo technologijų tobulinimo srityje. Šiuos pokyčius lemia gana didelis neatsinaujinančių išteklių stygius. Atsinaujinančių išteklių dalis dar nèra labai didelè, bet jų gausèja (1 lentelè). Pasaulio energetikos taryba (WEC) primena, kad išsivysčiusiose šalyse dar 30-40 metų atsinaujinantys energijos ištekliai sudarys nedidelę dalį energijos balanse. Artimiausius dešimtmečius jie (be didžiosios hidroenergijos) gali tik papildyti, bet ne pakeisti iškastinio kuro bei atominę energiją.

1 lentelè. Europa - 29 elektrinių rodikliai $2004 \mathrm{~m}$. (pagal WEC studiją $2007 \mathrm{~m}$.)

Table 1. Europe - rates of the 29 electric powerstations. 2004. (WEC study, 2007)

\begin{tabular}{lcccc}
\hline \multirow{2}{*}{ Elektrinių tipas } & lrengtoji galia & \multicolumn{2}{c}{$\begin{array}{c}\text { Metinè } \\
\text { elektros gmyba }\end{array}$} \\
\cline { 2 - 5 } & GW & $\%$ & TWh & $\%$ \\
\hline Atominės & 139 & 17,9 & 983 & 30,0 \\
\hline Šiluminès & 411 & 53,1 & 1694 & 51,6 \\
\hline Hidroelektrinès & 180 & 23,2 & 492 & 15,0 \\
\hline Atsinaujinančių išteklių & 45 & 5,8 & 111 & 3,4 \\
\hline $\begin{array}{l}\text { lš viso Europoje } \\
\text { (29 elektrinių rodikliai) }\end{array}$ & 775 & 100 & 3280 & 100 \\
\hline
\end{tabular}

Šiuo metu veikia daugiau kaip 20 tūkstančių vèjo jègainių, ịrengtų įvairiose pasaulio šalyse. Europoje vejo energetikos srityje šiuo metu pirmauja Vokietija, Ispanija ir Danija, kuri vien tik jūroje planuoja įrengti bendros $5000 \mathrm{MW}$ galios vèjo energijos jègainių. Lietuvoje iki $2010 \mathrm{~m}$. numatyta pastatyti $200 \mathrm{MW}$ bendros galios vejo jègainių, kurios gamins apie 2,5-3 proc. visos suvartojamos elektros energijos. Šiuo metu jau veikia keliasdešimties megavatų bendros galios vejjo jègainių parkai.

Lietuvos pajūryje jau plètojama ar bus plètojama ateityje tokių alternatyvios energetikos statinių ar ịrenginių statyba:

- Vèjo jègainių fermos ar pavienès jègainès.

- Saulès kolektoriai.

- Geoterminès jègainès.

- Mažosios hidrojėgainès.

- Jūros bangų energetiniai ịrenginiai. 
Lètai, bet vykdoma atskirų pastatų renovacija, kurios tikslas - sumažinti jų energetinius poreikius. Kai kurie ūkininkai pradeda planuoti energetinio miško auginimą.

Planuojama, kad artimiausiu metu Lietuva turètų pasigaminti $30 \%$ energijos iš alternatyvių šaltinių. Pajūryje tam yra ypač palankios išskirtinès sąlygos. Šiuo metu Vyriausybės strateginio planavimo komitetas nusprendęs, kad véjo energetika jūroje bus plètojama po $2010 \mathrm{~m}$.

Svarbūs Vakarų Lietuvos darnaus vystymosi prioritetai ir tikslai:

- Nuosaikus, tarp ūkio šakų ir kaimyninių regionų suderintas ekonomikos vystymas.

- Efektyvesnis gamtos išteklių naudojimas.

- Efektyvesnè kraštovaizdžio apsauga ir racionalus tvarkymas.

- Regiono kultūrinio savitumo išsaugojimas ir kt.

Lietuvoje perspektyvios elektrai gaminti atsinaujinančių energijos išteklių rūšys yra vandens ir vejjo energija. $2001 \mathrm{~m}$. ịsigaliojo Europos Parlamento ir Tarybos direktyva 2001/77/EC „Elektros energijos gamybos, naudojant atsinaujinančius energijos išteklius, vidaus elektros rinkoje skatinimas". Ši direktyva ES šalims narems nustato tikslą, kad iki 2010 m. atsinaujinančių energijos išteklių dalis šalies kuro balanse sudarytų $12 \%$, o pagaminta iš šių išteklių elektros energijos dalis $-22,1 \%$ visos šalyje suvartojamos elektros energijos.

Klaipedos apskritis turi didžiausią potencialą Lietuvoje plètoti netradicinius energijos gavimo būdus, ypač vejjo energetiką, taip pat naudoti kitus atsinaujinančius energijos šaltinius (pvz.: geoterminę energiją, jūros bangų energiją), tačiau svarbu visai tai sistemai plètojantis taip pat išlaikyti dermę ir su kraštovaizdžio sistema.

Saugant energijos išteklius, siūloma regione skatinti atsinaujinančių energijos šaltinių naudojimą, t. y. naudoti vẻjo, vandens, geoterminę energiją gyventoju ir ūkio subjektų poreikiams tenkinti. Siūlomos vejo jègainių statybos vietos yra išskirtos atsižvelgiant $i$ vidutinị vèjo greitị apskrities teritorijoje. Didesnè galimybė vèjo jègainèms statyti yra Skuodo, Kretingos, Vilkyčių, Klaipèdos apylinkèse (pirmaeilès teritorijos); yra galimybè - Vèžaičių, Šilutès apylinkèse (antraeilès teritorijos). Galimos vietos geoterminèms jègainèms statyti yra Klaipedos miesto pietineje dalyje esančios inžinerinès infrastruktūros teritorijos ir Palangos miesto rytinèje dalyje esančios pramoninès teritorijos (Palangos... 2008).
Kai Palangos įtakos zonoje (Šalia Vydmantų gyvenvietės) iškilo pirmoji parodomoji pramoninè vejjo jègainè (2003 m. pastatyta Kaišiadorių ir Magdeburgo vyskupijos iniciatyva), prieštaraujančių nebuvo, atvirkščiai - atvažiuojantys iš kitų Lietuvos regionu džiaugdavosi šiuo nauju ir ịdomiu objektu. Kultūriniam kraštovaizdžiui šis objektas didesnio poveikio neturèjo. Važiuojančius ị Palangą valstybiniu keliu A11 jègainès vertikalè pasitinka kelio panoramos viduryje. Vieta buvo parinkta racionaliai - magistralinio dujotiekio apsaugos zonoje (2 pav.).

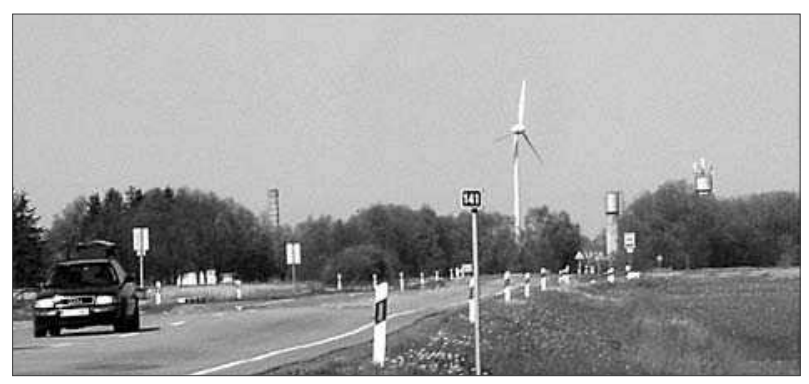

2 pav. Pirmoji vejjo jègainè ties Vidmantais, Kretingos-Palangos kelio perspektyvoje

Fig. 2. First windpowerstation near Vidmantai

Vèliau (2004 m.) suplanuotos ir pastaty tos 6 vèjo jègainès šalia kelio Klaipèda-Palanga, tačiau pažeidžiant planavimo procedūras ir vietos gyventojams pasipriešinus nebuvo suteiktas leidimas jų eksploatacijai. Jos buvo demontuotos ir išvežtos.

$2006 \mathrm{~m}$. Lietuvos pajūrio žemyninëje dalyje (3 pav.) pradètas statyti didžiausias Baltijos šalyse (30 MW galingumo) 15 vèjo jègainių parkas. Šių jègainių teritorija patenka ị kurorto apsaugos zoną. Šioje teritorijoje dar papildomai buvo suplanuotos 5 vejjo jègainès (Mureika, Grecevičius, Trutnevis 2008). Deja jègainès nebuvo sukoncentruotos viename lauke, bet išbarstytos didelèje ekstensyviai urbanizuotoje teritorijoje tarp privačių sklypų nedidelemis grupelemis.

Tuo pačiu laikotarpiu (2006 m.) buvo statomas ir antras vejjo jègainių parkas Kretingos rajono šiaurinèje dalyje. Ne tokiose urbanizuotose ir neperspektyviose teritorijose jos ir prieštaravimų mažiau susilaukia (3 pav.). Šiuo metu vejo jègainių statyba plečiasi Klaipèdos ir Šilutės rajonų teritorijose. Perspektyvių teritorijų vejjo energetikai plètoti yra Skuodo ir Mažeikių rajonų teritorijose. Šiuo metu nei pamario, nei Kuršių nerijos zonose vejo jègainių statyti dar neketinama. Tačiau planuojama statyti jègainių parkus Nemuno 


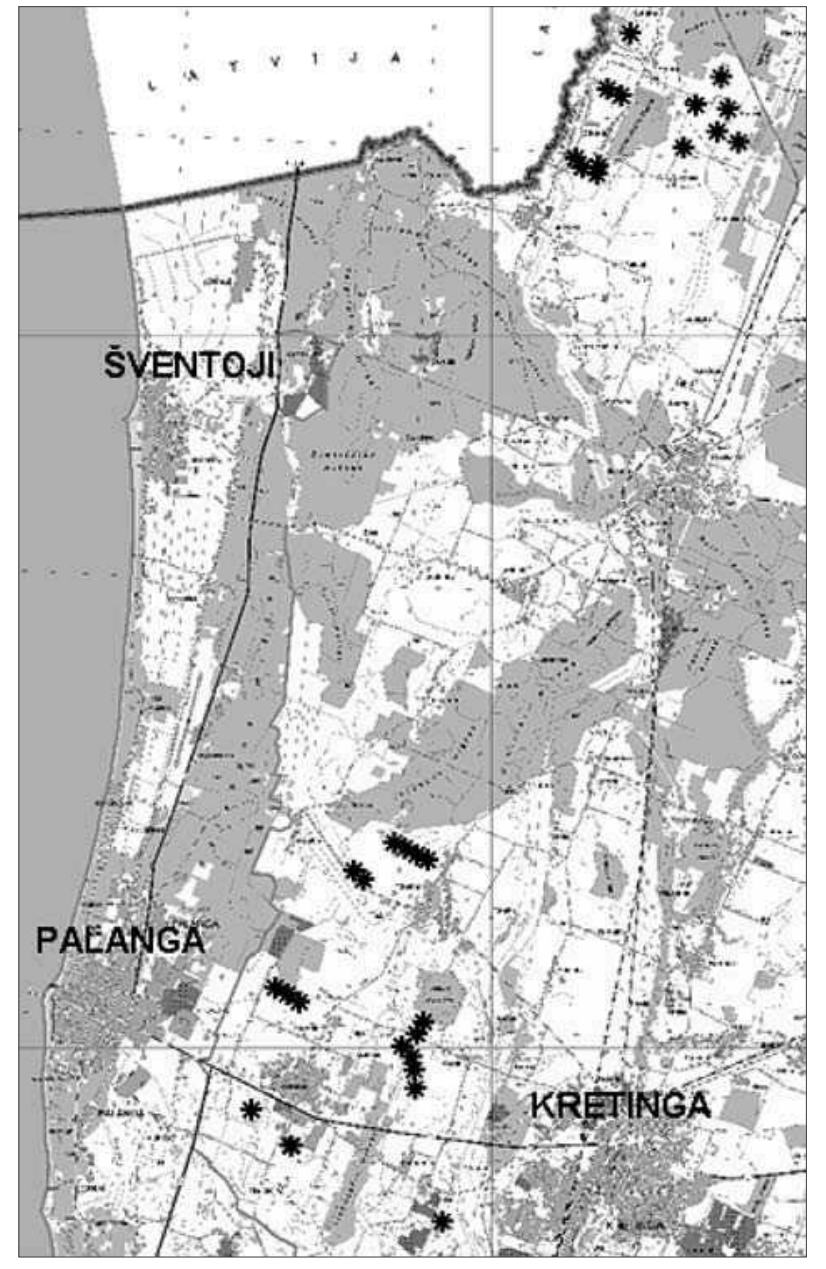

3 pav. Vèjo jègainių dislokacija Kretingos rajono pietvakarineje ir šiaurineje dalyse

Fig. 3. Location of windpowerstation farms in Kretinga district

deltos regioninio parko prieigose ir šalia Juknaičių gyvenvietès. Pradèti jègainių statybos atviroje jūroje tyrimai. Tačiau LR Vyriausybès strateginio planavimo komiteto sprendimu vèjo energetika jūroje gali būti pradèta plètoti tik po $2010 \mathrm{~m}$.

\section{Alternatyvios energetikos objektų įtaka pajūrio kraštovaizdžiams}

Pradejjus naudoti alternatyvius energijos gavybos būdus regiono teritorijoje atsiranda atitinkamų objektų (vejo jègainių, hidroịrenginių, geoterminès šilumos jègainių ir kt.), kurie gan drastiškai veikia regiono kraštovaizdị.

Vèjo jègainès - ypatingu statinių kategorija, statytojai akcentuoja, kad vèjo jègainių bokštai keičia, tačiau nedarko vietovès kraštovaizdžio. Aukštos $78 \mathrm{~m}$ vejjo elektrinių gondolos ir sparnuotės nudažytos šviesiai pilka, pereinančia i̇ žalumą spalva, kuri susilieja su dangaus ir žalumos fonu ir sudaro ị akị nekrintantị, natūralios gamtos ir bokštinių statinių derinị, taip esamas kraštovaizdis ịgyja naują kokybę. Tačiau detaliau analizuojant pastebima, kad jų statymo vietas buvo galima tiksliau parinkti, taip pat kyla diskusijų ir dèl jègainių skaičiaus bei išdèstymo gyvenviečių atžvilgiu.

Lietuvos pajūrio gyvenviečių bei rekreacinių teritorijų uždavinys suteikti galimybę žmonèms efektyviai naudotis Lietuvos rekreaciniais ištekliais (Steenwegen 2003). Tai įmanoma tik racionaliai naudojant turimas gamtos ir kultūros vertybes, tarp kurių unikalų vaidmenį atlieka kompleksiniai kraštovaizdžio dariniai (Simonds 1983).

Alternatyvios atsinaujinančios energijos naudojimas veikia kraštovaizdžius dvejopai: teigiamai ir neigiamai. Teigiamas poveikis pasiekiamas dèl kieto kuro, naftos degimo procesų sumažèjimo, mažèjančių transportavimo srautų ir kt. Vertinant tai, kad iškasami ištekliai po kurio laiko baigsis, bus visiškai pereita prie atsinaujinančios energijos naudojimo. Neigiamą poveikị šiuo metu daugiausia daro griozdiški vèjo jègainių įrenginiai ir bangų energetiniai ịrenginiai (4 pav.).
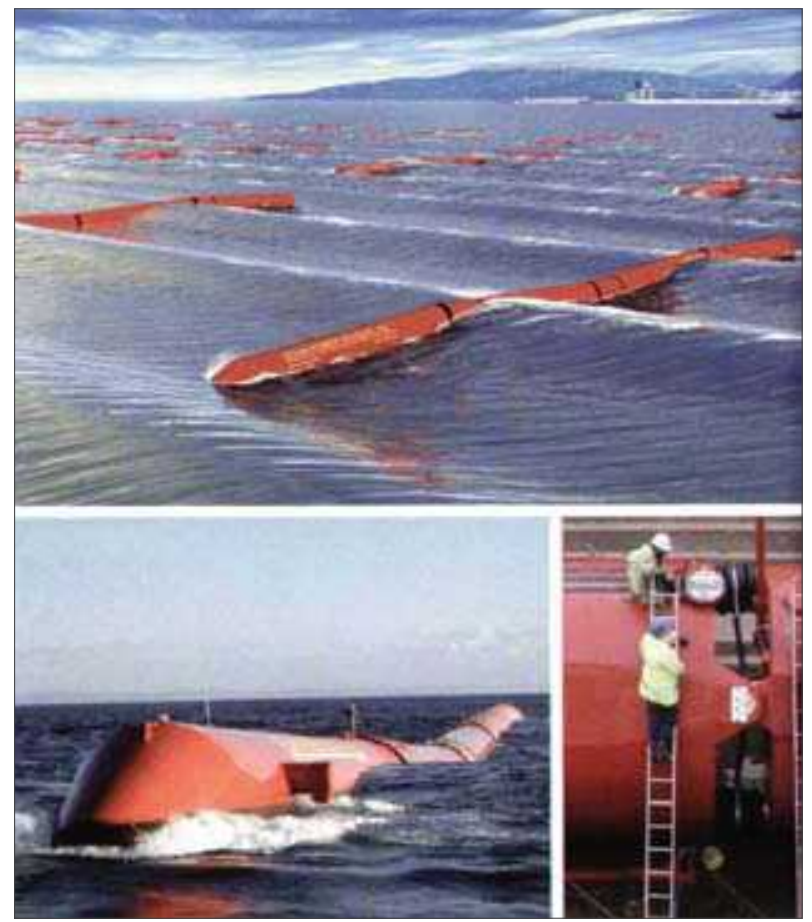

4 pav. Bangu energetiniai įrenginiai, darantys stipru vizualini poveiki jūriniams kraštovaizdžiams

Fig. 4. Inpacts of wavepowerstations for quality of sea landscape 
Saulès kolektoriai ant stogų ir pastatų sienų iš esmès keičia tradicinès architektūros vaizdą (5 pav.). Raudonstogiai senamiesčiai, čerpiniai šlaitiniai istorinių pastatų stogai suskaidomi tamsiomis saulès kolektorių dèmèmis. Taip gali būti prarastas tradicinès architektūros emocinis poveikis (Barlow 2001). Saulès kolektorius, mažoji vejo jègainè - tai papildomas veiksnys originaliai stogų ir sienų formai išgauti, galimi nauji modernūs architektūriniai sprendimai, galintys
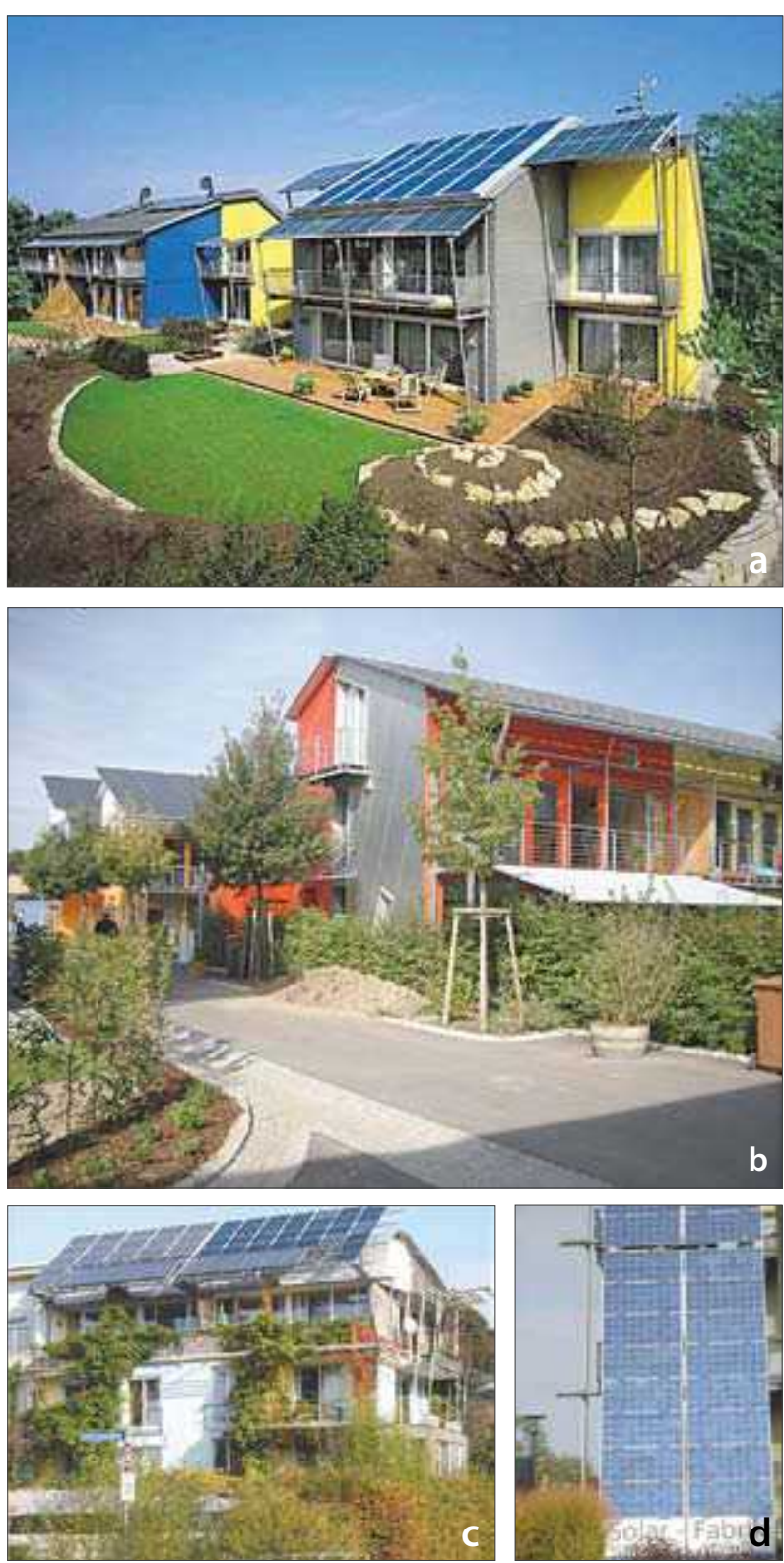

5 pav. Saulès energiją kaupiantys namai. Pastatų stogai, dengti saulès kolektoriais, kurie keičia jų architektūrinę raišką $(a, b, c, d)$

Fig. 5. Architecture of new buildings with sun-power collectors $(a, b, c, d)$ pagyvinti ir pagerinti regiono architektūrinès aplinkos savitumą.

Analizuojant esamą situaciją Lietuvos pajūrio zonoje būtina išskirti Palangos rekreacinį arealą. Lietuvos žmonių rekreacinių interesų požiūriu, žemyninèje dalyje Palangos zona rekreacijai organizuoti neabejotinai svarbiausia. Jos tvarkymo politikai igyvendinti skirta visa serija urbanistinio planavimo darbų. Palangos kurorto buferinè zona - svarbus potencialas rekreaciniu paslaugų plètrai kurorto prieigose. Todèl vejjo jègainių plètra čia netoleruotina.

Prognozuojamas alternatyvios energetikos statinių ir įrenginių poveikis regiono socialinei aplinkai. Neabejotina ịtaka Klaipedos regiono, Palangos, Neringos, Klaipėdos miesto ir Klaipedos rajono savivaldybių teritorijų kraštovaizdžių vizualinei raiškai, rekreacijos ir gamtosauginio ūkių struktūros pokyčiams, rekreacinių gamtinių išteklių fondui ir jo racionaliam naudojimui.

Savo ruožtu pajūrio rekreacinių kraštovaizdžių kokybè nulemia bendrųjų investicijų ir verslo sąlygas, daro įtaką pajūrio rekreacinio arealo konkurencingumui šalies ir užsienio rinkose, valstybès ir savivaldybių biudžetams (Shaw 1997).

Regiono gamtos ištekliai turi būti tausojančiai naudojami ir papildomi tvarkant bei plètojant saugomas teritorijas, taip pat rūpinantis kraštovaizdžio ir gamtos vertybių išsaugojimu (Lamauskas 2003), naudojimu rekreacijai bei turizmui, vystant jų infrastruktūrą (Stauskas 2006). Taip pat turi būti kur kas efektyviau naudojami ir papildomi atsinaujinantys ir racionaliau naudojami neatsinaujinantys regiono gamtos ištekliai, atliekamas jų auditas ir skiriamas deramas dèmesys pramoninių telkinių teritorijoms rekultivuoti, tvarkomi vandens telkinių, ypatingai Baltijos jūros krantai. Taikant jūrinès krantotvarkos technologijas gali būti suderinami ne tik krantosaugos interesai, bet ir papildomai išgaunama energija, tinkamai ịrengus bangolaužius, pirsus, kuriuose būtų integruoti bangų energiją akumuliuojantys įrenginiai (6 pav.).

Kraštovaizdžio planavimo politika 2009-2020 m. laikotarpiu Lietuvos pajūryje bus labai stipriai veikiama šiuo metu besiformuojančios Lietuvos jūrinès metropolijos. Vienas pagrindinių gyvenimo kokybės elementų - apsirūpinimas kokybišku būstu ir gyvenamosios aplinkos kokybė. Nors apsirūpinimas būstu daugiausia yra kiekvieno piliečio asmeninis reikalas, tačiau valstybè gali padèti šiame procese vykdydama teritorijų, skirtų būsto plètrai, kompleksinị planavimą ir prižiūrèdama jų inžinerinị parengimą, formuodama 


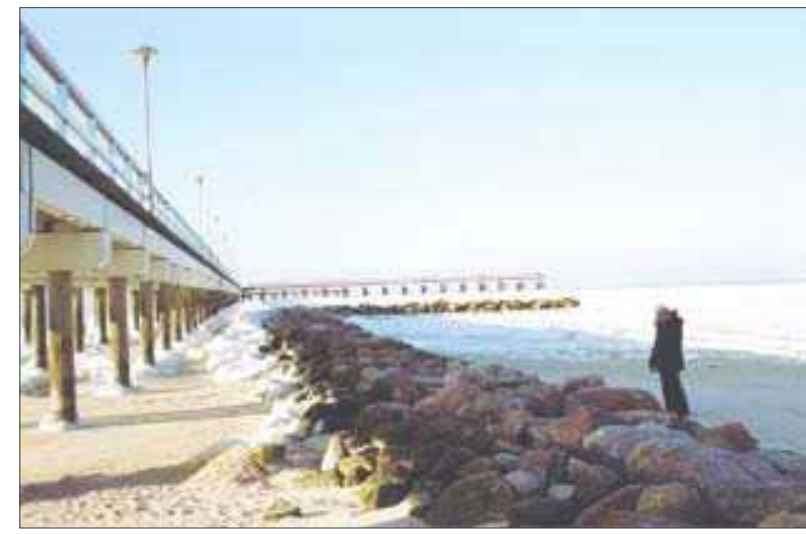

6 pav. Tinkamai sutvarkyti statiniai galètu veikti kaip krantu stabilizavimo ir kaip bangu energetikos jègainès

Fig. 6. Sea bridge and pier - potential wave powerstations

gyvenviečių želdynų ir rekreacinių teritorijų sistemas, kartu su gyventojais humanizuodama ir gerindama aplinką tankiai daugiabučiais namais užstatytose gyvenamosiose zonose bei kitose teritorijose. Taip, šalia kompleksinio senụjų pastatu renovavimo, turi būt rūpinamasi efektyviu alternatyvios energetikos šaltinių naudojimu.

Tačiau tinkamai nereglamentuota veikla gali pridaryti daug žalos aplinkos architektūrai ir kraštovaizdžių kokybei. Gyvenviečių kraštovaizdžio kokybei gerinti reikia keisti teisinę bazę, parengti bei įtvirtinti architektūrinius ir kraštovaizdžio reglamentus planavimo praktikoje. Modernių technologijų sprendimai ir jų itaka turi remtis sistemingais kompleksiniais moksliniais tyrimais.

\section{Išvados}

1. Alternatyvios atsinaujinančios energetikos vystymo potencialas Lietuvos pajūrio areale labai didelis. Lyginant su kitais Lietuvos regionais, čia yra didžiausi ekologiškos energetikos ištekliai: stiprūs jūriniai vejjai ir bangos, geoterminiai vandenys, daugiausiai saulètų dienų.

2. Pirmieji praktiniai bandymai plètojant vẻjo energetiką parodè, kad šalia teigiamo šios energetikos rūšies veiksnių yra daugybè negatyvaus poveikio aplinkai veiksnių. Kadangi vejjo jegainių statybos procesui Lietuvoje nebuvo tinkamai pasirengta (neparengta teritorinè strategija, nèra reikiamos normatyvinès dokumentacijos, LR teritorijos bendrajame plane nenumatytos teritorijos ir sąlygos, kuriomis galètu būti formuojami vèjo jegainių parkai), pirmosios vejo

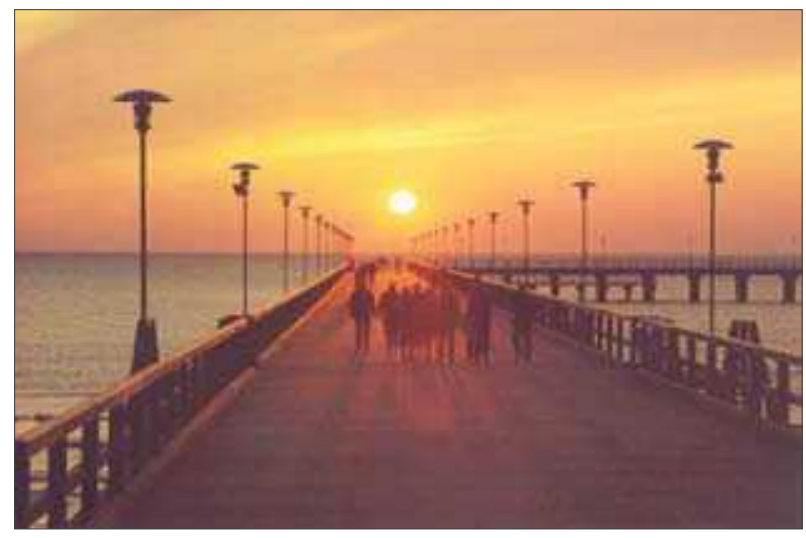

7 pav. Saulès palydų tradiciją gali sutrikdyti planuojami vejuy jègainių parkai jūroje

Fig. 7. Windpowerstation farms in the sea can disturb old tradition of sundown showing

jègainès ar jų grupès dėstomos pažeidžiant kitus svarbius aplinkosaugos, valstybinių saugomų teritorijų, vietinių bendruomenių, kraštovaizdžio, rekreacinio naudojimo interesus.

3. Pajūrio gyvenviečių kraštovaizdyje ypač svarbios yra atviros gamtinès erdvès, miškai ir miško parkai. $\mathrm{O}$ vejo jègainių atsiradimas Palangos kurorto (7 pav.) ir Pajūrio regioninio parko rytinèse prieigose stipriai sumažina šių teritorijų rekreacinę vertę. Vejo jẻgainių teritorini paskirstymą būtina atlikti kompleksiškai ivertinant ilgalaikio poveikio pasekmes ir, kas svarbiausia, nepažeisti 5-7 km pločio pajūrio teritorijų, kraštovaizdžio vientisumo.

4. Spartejant statyboms aplink Klaipèdą, formuojasi Klaipèdos jūrinè metropolija. Sisteminio planavimo darbai modeliuojant urbanizacijos procesus šiame areale nevykdomi. Nevykdomi vejjo, bangų, saulès ir kt. energetikos statinių bei ịrenginių integravimo ¡̇ kraštovaizdị kryptingo tikslinio formavimo darbai, neparengta regiono reprezentacinių teritorijų ir kelių kraštovaizdžio formavimo koncepcija.

5. Siekiant išvengti negatyvaus alternatyvios atsinaujinančios energetikos statinių ir įrenginių poveikio, būtina parengti Vakarų Lietuvos alternatyvios atsinaujinančios energetikos išdèstymo ir jau esančių jègainių poveikio sumažinimo specialujji planą, vykdyti mokslinius tyrimus, užtikrinančius patikimą metodinị atsinaujinančios energetikos statinių ir ịrenginių integravimo ị pajūrio kraštovaizdị pagrindą, kuris padètų išsaugoti ir stiprinti Lietuvos pajūrio architektūrinio savitumo bruožus. 


\section{Literatūra ir šaltiniai}

Barlow Rogers, E. Landscape Design. 2001. New York.

Grecevičius, P.; Marčius, R. 2006. Rekreacinio kraštovaizdžio erdvinès struktūros formavimo strategijos aspektai stiprinant Lietuvos kultūrinị identitetą Baltijos šalių kontekste, Urbanistika ir architektūra XXX (2): 87-96.

Grecevičius, P. 2001. Subalansuotos ükines veiklos problemos ir tendencijos Lietuvos pajūrio ruože. Kaunas: Technologija.

Mureika, A.; Grecevičius, P.; Trutnevis, V. ir kt. 2008. Kretingos rajono bendrojo plano sprendiniai. Klaipeda.

Lamauskas, A.; Bučas, J.; Dringelis, L. 2003. Kultūrologiniai kraštovaizdžio ir architektūros paveldo tyrimai. Kaunas.

Lietuvos Respublikos teritorijos bendrasis planas. 2002. Vilnius: „UAB Urbanistika“.

Palangos miesto bendrasis planas. 2008. Vilnius.

Simonds, J. O. 1983. Landscape Architecture. USA.

Stauskas, V. 2006. Pajūrio kraštotvarkos politika: kryptinga sistema ar dar ne? Archiforma 1: 36-41.

Shaw, G.; Williams A. M. 1997. Critical Issues in Tourism. A Geographical Perspective. Oxford.

Steenwegen, L.; Adams, N. 2003. Vakaru Lietuvos regiono erdviné strategija. Klaipèda.

Vakarų Lietuva 2020. Klaipédos apskrities bendrasis planas. Preliminariniai sprendiniai. 2002. Klaipèda.

\section{SOME ASPECTS OF THE IMPACT OF ALTERNATIVE ENERGY STRUCTURES AND INSTALLATIONS ON THE ARCHITECTURE OF BUILDINGS AND SEASIDE LANDSCAPES}

\section{P. Grecevičius, J. Abromas, V. Dubra}

Abstract. Lately there are increasing signs of urbanization in the West Lithuanian landscapes which have an influence on the identity of the region, its historic and natural environment values. Housing development among seaside settlements is increasing. Lately some complexes of wind - power stations were installed. Unfortunately, they are built too close to residential areas, cultural heritage and landscape values. It is planned to install wind - and wave-power station fields in the high sea. Separate sun-power collectors are built on building roffs. Small-sized hydropower stations areconstructed or renovated. All these objects undoubtedly have an influence on building architecture and seaside lanscapes. On the basis of investigation data on some Lithuanian seaside settlements, useful planning and juridical suggestions are presented in the work to ensure sustainable development of the seaside region.

Keywords: landscape, architecture, alternative energy, sustainable development, identity.

\section{PETRAS GRECEVIČIUS}

Doctor of the Humanities (arch.), Prof, Dept of Landscape Architecture and Environmental Design, Research Institute of Maritime and Cultural Landscape, Klaipeda University, H. Manto g. 84, LT-92294, Klaipeda, Lithuania.

E-mail: petras.grecevicius@ku.lt

Teaching: landscape architecture, urban design, territory planning, recreation and tourism. Research interests: architecture, urban design, recreation and tourism, strategic planning, humanization of architectural environment.

\section{JONAS ABROMAS}

Assistant, Dept of Landscape Architecture and Environmental Design, Research Institute of Maritime and Cultural Landscape, Klaipeda University, H. Manto g. 84, LT-92294, Klaipeda, Lithuania. Doctoral student, Kaunas Technological University.

E-mail: jonasabromas@yahoo.com

Research interests: architecture, urban design, humanization of architectural environment. Teaching: landscape architecture, territory planning,

\section{VYTAUTAS DUBRA}

Doctor of Science, Assoc Prof, Dept of Landscape Architecture and Environmental Design, Research Institute of Maritime and Cultural Landscape, Klaipeda University,

H. Manto g. 84, LT-92294, Klaipéda, Lithuania.

E-mail:vdubra@gmail.com

Research interests: hydrology, urban design. Teaching: hydrology, landscape architecture, territory planning. 